\title{
Comparison of apricot cultivars for suitability for organic growing
}

\author{
Dremák Péter \\ University of Debrecen, Institute of Horticultural Sciences \\ H- 4032 Debrecen, Böszörményi 138 \\ dremak@agr.unideb.hu
}

Keywords: apricot cultivars, regeneration, organic growing

Summary

\begin{abstract}
Nowadays, important task is using more widely the environmentally friendly production technologies. There are considerable differences among technologies using reduced spray programs (integrated and organic) in plant protection and plant nutrition.

In this case integrated production has a better position as roles for organic production more strict and due to this fruits has an obvious temporal and permanent reduction in tree conditions. Fitotechnical elements and renewal and regeneration of cultivars are important factors for offseting or delaying of condition weakening.

In this study, 5 apricot cultivars (not pruned for 8 years) were compared in their characteristics (assessment of inactive, semi-active and active plant parts).

Our study showed that there were 50-70\% differences among observed characteristics. Our study confirmed those cultivars which are suitable for organic production and which one more resistant to condition weakening and which one able to tolerate negative technological effects.
\end{abstract}

\section{Introduction}

Nowadays it is more and more important to use technologies which are not harmful for environments, producer and consumers. There are considerable differences among technologies using reduced spray programs (integrated and organic) in plant protection and plant nutrition.

In this case integrated production has a better position as roles for organic production more strict and due to this fruits has an obvious temporal and permanent reduction in tree conditions. Fitotechnical elements and renewal and regeneration of cultivars are important factors for offseting or delaying of condition weakening.

The main domestic apricot production is performed in Duna Tisza region (Papp, 2004). Rootstock is mainly wild apricot. This rootstock has good environmental resistance. Some nurseries use myrobalan plums for rootstocks as they are protect trees against Pseudomonas and Cytospora infection as well as these trees grows more slowly (Hrotkó, 1999). Apricot grows spherical or spreading type crown form. For both type of crown those prunings are needed which provided a good yield production and vegetative activity is balanced as well as condition are optimal (Gonda 2010). In case of pruning we have to consider also plant protection. There is a great importance of disinfecting equipments used in the orchards (Holb, 2005). We also need to select dormant bud and blossoming period for performing pruning (Klement, 1984).

In this study, 5 apricot cultivars (not pruned for 8 years) were compared in their characteristics (assessment of inactive, semi-active and active plant parts).

\section{Materials and methods}

Cegléd Fruit Research Station was used as an experimental orchard. Crown habitat and production branches (active, dead) were evaluated for 5 cultivars. These characteristics were drawn on paper and we compared the observed tree parts. Knowing this, we compared cultivars and made order among them. Examined cultivars were 'Ceglédi bíbor', 'Ceglédi piroska','Gönci magyar kajszi', 'Ceglédi óriás' and 'Mandulakajszi'.

\section{Results}

Cultivar 'Ceglédi bíbor' has the best regeneration capacity, there were only very few dead branch part in the trees. Only $20 \%$ dead parts were observed. This was observed as a good result. In figure 1, dead parts were drawn with black colour. 


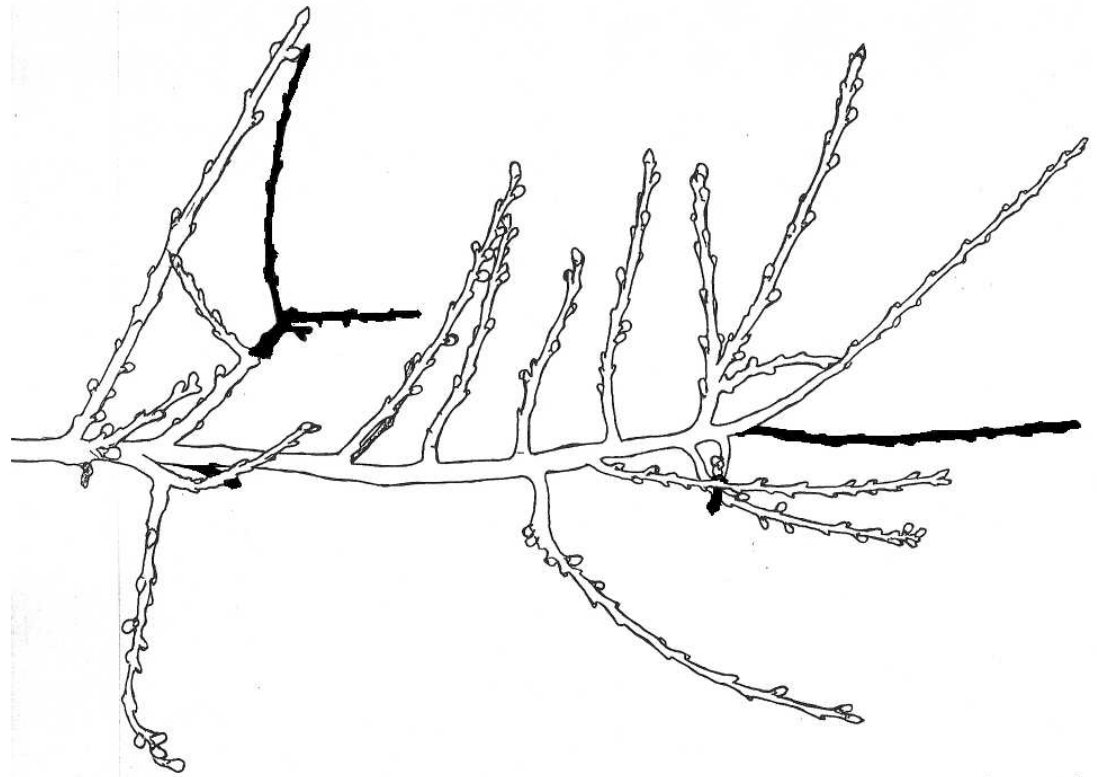

Figure 1.: Branches of cultivar 'Ceglédi bíbor'

Cultivar 'Ceglédi piroska' has the worst regeneration capacity, there were a lot of dead branch part in the trees. Almost $70 \%$ dead parts were observed. In figure 2. dead parts were drawn with black colour.

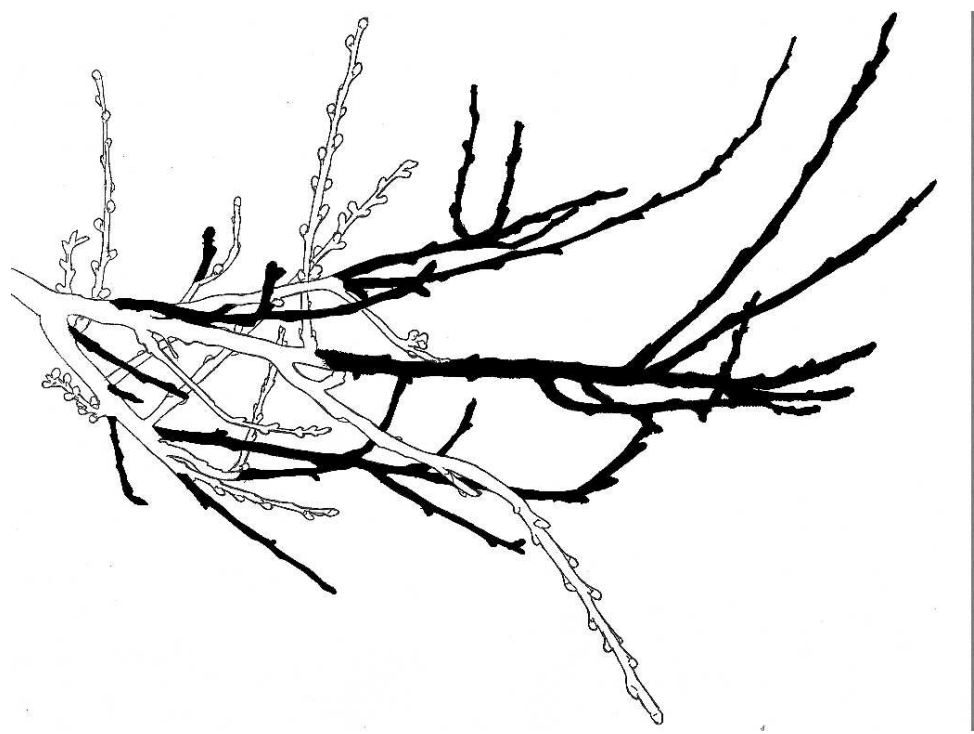

Figure 2.: Branches of cultivar 'Ceglédi piroska'

For other cultivars we also compared the living and dead part of the trees. This can be seen in Figure 3. 


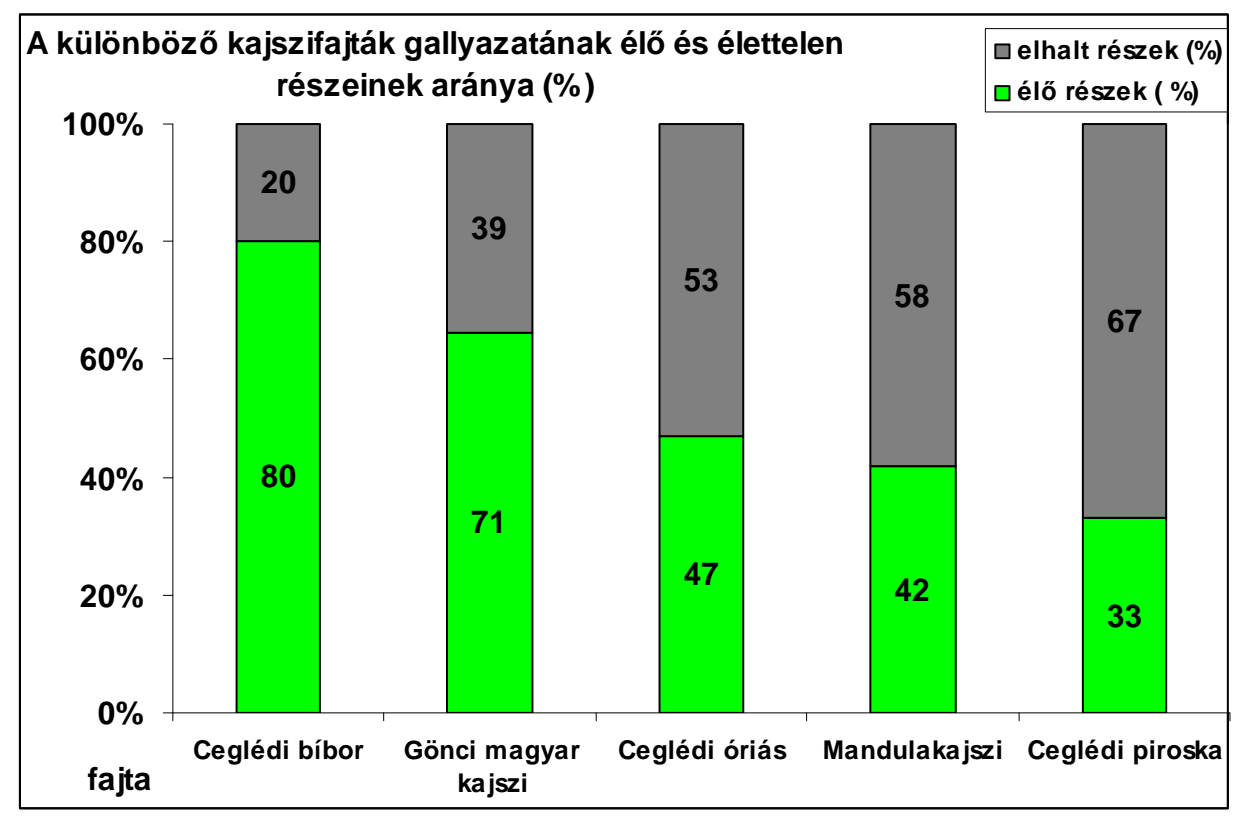

Figure 3: Dead and living branch parts of 5 apricot cultivars

It can be seen in the figure that cultivar 'Ceglédi bíbor' has the best regeneration capacity, there were $80 \%$ living branch parts. Cultivar 'Gönci magyar kajszi' could also be considered as good (70\% living branch parts). Cultivars 'Ceglédi óriás' and 'Mandulakajszi' had less than 50\% living branch parts. Cultivar 'Ceglédi piroska' has the worst regeneration capacity, only $30 \%$ living parts were observed on the trees.

We can conclude that after many years without pruning can cause differences among active and inactive branch parts of the trees. The tree can be considered active if the dead branch parts are low. Therefore in organic production, those cultivars has priority which has large living branch parts after several years of unpruning.

\section{References}

Gonda, I. (2010). Csonthéjas gyümölcsfák metszése. Debreceni Egyetem AMTC Kutatási és Fejlesztési Intézet és Gonda István Bt. kiadásában, Debrecen, 242.p.

Holb, I. (2005) A gyümölcsösök és a szőlő ökológiai növényvédelme. Mezőgazda Kiadó, Budapest, 341.p. Hrotkó, K.(1999). Gyümölcsfaiskola. Mezőgazda Kiadó, Budapest

Klement, Z. (1984) Baktériumos betegségek. 48-69. In. Jenser G. (ed.): Gyümölcsfák védelme. Mezőgazda Kiadó, Budapest

Szalay, L. (2004). Kajszi. 209-232. In. Papp J. (ed.): A gyümölcsök termesztése. Metzőgazda Kiadó, Budapest http://www.vm.gov.hu/main.php?folderID=1624\&articleID=5928\&ctag=articlelist\&iid=1 $\quad(150 / 2004 . \quad$ X. 12. FVM. Rendelet) 